\title{
TEMPORARY CONTRACTS AND MANUFACTURING FIRMS' OUTCOMES IN SPAIN: A CURVILINEAR EXAMINATION
}

\begin{abstract}
This work contributes to research on temporary employment, specifically through an analysis of its effect on firm efficacy. We analyze the potential curvilinear (nonlinear) relationship between temporary contracts and organizational outcomes and examine how the proportion of indirect temporary workers-hired through Temporary Help Agencies (THAs)—influences this relationship in a sample of 1,597 Spanish manufacturing firms. We find a negative linear relationship between temporary contracts and labor productivity and a predominantly positive concave downward curve between temporary contracts and gross operating margin. This curvilinear relationship is especially stronger when the proportion of indirect temporary contracts is low, and we find that the use of temporary contracts has a positive effect on gross operating margin, but this effect becomes negative with overuse. This empirical evidence partially questions the dominant linear paradigm that has been established over the past few decades in the labor flexibility literature at an organizational level.
\end{abstract}

Keywords - Temporary employment, curvilinear relationship, types of temporary employment, labor flexibility, organizational outcomes. 


\section{INTRODUCTION}

Faced with incessantly increasing competition and uncertainty, organizations need the capacity to adapt quickly to market fluctuations and changes in their environment to maintain their competitiveness and survive. This requirement for flexibility has appeared in various organizational aspects, affecting competitive strategies, production methods, the design of organizational structures and human resource management (Atkinson, 1984; Michie and Sheehan, 2001). In this last aspect, capacity to adapt is defined as labor flexibility. This concept covers very different kinds of human resource management policies and practices, which have been grouped into two basic categories: internal or functional flexibility, and external or numerical flexibility (Kalleberg, 2001; McIlroy, et al., 2004; Roca-Puig et al., 2008a). Internal labor flexibility refers to the firm's efforts to incorporate and develop workers' competences and skills, so that a worker can be assigned to other jobs or departments within the firm. External labor flexibility concerns the capacity to change the number of workers hired in order to quickly and efficiently adapt the volume of work to changes in demand.

In the last few years recourse to external labor flexibility has become the central core around which employment policy—seeking a solution to unemployment - has been based in the European Union (EC, 2005, 2010). In particular, in Spain, firms have developed external labor flexibility largely through temporary contracts, rather than through other practices such as part-time work or subcontracting (EC, 2005, 2010; Sánchez and Toharia, 2000). The generalization of this type of contract in Spain has led to the so-called "temporary contract culture" (Toharia, 2005). As a result, much of the empirical research in the Spanish setting focuses on the individual level of analysis, characterizing temporary jobs, identifying the reasons why they are intensively used and their impact on workers' attitudes (e.g. AmuedoDorantes, 2000; De Cuyper et al., 2009; Silla et al., 2005). A similar approach has been taken 
in research in the European setting (e.g., De Cuyper and De Witte, 2007; Lozza et al., 2013; Mauno et al., 2012). However, in Spain, as well as in other countries, at the organizational level of analysis the empirical literature examining the effect of temporary contracts - as the predominant form of external labor flexibility—on firm performance is still scarce (Forrier and Sels, 2003; Lepak et al., 2003) and apparently contradictory.

Authors such as Cardon (2003), Davis-Blake et al. (2003), George (2003), Lepak et al. (2003) and Valverde et al. (2000) warn of the paradoxical effect that the use of temporary contracts can have on organizational outcomes: on the one hand, they are beneficial in that they allow firms to adapt to market fluctuations more rapidly, to obtain specialized services or skills that are not available in-house, and to reduce labor costs; however, they are also costly since they are a barrier to temporary workers' motivation and integration in the firm, and may lead to conflicts between temporary and permanent workers. Therefore, the use of temporary contracts derives in uncertain organizational outcomes, and contradictory results are frequently found in the empirical literature analyzing the effect of temporary contracts on organizational outcomes (De Cuyper et al, 2008). On the one hand, there are studies that point to the existence of a positive effect (Lepak et al., 2003; Valverde et al., 2000). On the other hand, however, other researchers demonstrate a negative effect (De Grip and Sieben, 2005; Diaz-Mayans and Sánchez, 2004). Lastly, still other works find no significant effect (MatíasReche, 2003; Michie and Sheehan-Quinn, 2001; Roca-Puig et al., 2008a). Consequently, an intense debate currently surrounds the issue of how useful temporary hiring is at firm level.

Our central aim in this paper is to reconcile these apparently conflicting results by proposing that a curvilinear relationship exists between temporary contracts and organizational outcomes. In this respect, Aiken and West (1991) and Pierce and Aguinis (2013) note that when opposing theoretical proposals forecast relationships where two variables have different signs, and when empirical studies produce mixed results, the 
possibility should be considered that the relationship between these two variables might be curvilinear. In this case, a point of inflection (maximum and minimum of the curve) is seen where the change of sign occurs, and therefore a negative relationship can coexist with a positive relationship. Since the presence of curvilinear relationships has been noted in some domains, a paradigmatic shift from linear to curvilinear models is needed to improve management theory and practice (Pierce and Aguinis, 2013). In other words, we can explain the inconsistent findings with respect to the impact of temporary employment on organizational outcomes by introducing the level of temporary contracts that already exists in the firm as a potential moderator. The quadratic component of temporary contracts in a regression equation mathematically represents this moderator (i.e. curvilinear) effect in our study. ${ }^{1}$ Aunque previous empirical studies have explored how the relationship between temporary employment and organizational outcomes can be modified by other human resource practices and contextual factors (e.g., Lepak et al., 2003; Michie and Sheehan, 2001; Roca-Puig et al., 2008a), curiously, the degree to which a firm utilizes temporary hiring has not yet been analyzed as a moderator variable. The main contribution of this study is to bridge this gap.

We expect to find significant differences in organizational outcomes not only across varying levels of temporary contract use, but also across types of temporary contracts. Temporary work is not a homogeneous category (Broschak and Davis-Blake, 2006; De Cuyper et al, 2008; Houseman et al., 2003; Mitlacher, 2007). The implication for organizations contracting temporary labor services for different types of temporary employment, in particular the use of Temporary Help Agencies (THAs) as opposed to shortterm direct employment arrangements, is still an issue that requires further investigation (Houseman et al., 2003). Indirect temporary contracts represent a special kind of temporary

\footnotetext{
${ }^{1}$ The nonlinear relations can be conceptualized as a special case of the more general moderated relations (Pierce and Aguinis, 2013).
} 
employment, in which workers are legally employed by an external agency and work on a day-to-day basis at the premises of another firm (García-Pérez and Muñoz-Bullón, 2005). This position gives rise to questions such as whether the relationship between temporary hiring and organizational outcomes differs according to the proportion of temporary agency employment in relation to direct-hire temporaries. The second aim of this paper is to provide a response to this question.

\section{CONCEPTUAL FRAMEWORK}

\subsection{Temporary contracts in Spain}

If one is looking for a country in which to test the effect of temporary contracts on organizational outcomes, Spain provides a fascinating case study because Spanish firms have developed external labor flexibility mainly through temporary contracts (Dolado et al., 2002). Figures from the last decade reveal that Spain has the highest proportion of temporary contracts in the European Union, twice the rate of countries such as France or Germany, and more than three times that of Belgium or Italy (EC, 2005, 2010). This proportion is nearly twice that of the United States (Amuedo-Dorantes, 2000). The generalized use of temporary contracts in Spain needs to be understood in its own socioeconomic context. It is necessary to locate issues of flexibility more securely within both existing national regulatory and institutional frameworks (Blyton and Martínez-Lucio, 1995; Kalleberg, 2001). The serious unemployment situation in the ' 80 s in Spain led to temporary contracts becoming generally permitted without the need for explanations (Toharia, 2005) ${ }^{2}$. Even after the regulation reforms of 1997, 2001, 2006 and 2010, introduced to stimulate permanent contracts, Spanish governments have not been very successful in their attempts to reduce temporary hiring

\footnotetext{
${ }^{2}$ Unemployment has been a major feature in the Spanish labor market's recent history, reaching rates greater $20 \%$ al least three times since early 1980s: the worst performance of the EU-27, with a rate of $21.52 \%$ in the third quarter of 2011 (Fernández-Rodríguez and Martínez-Lucio, 2012).
} 
(Fernández-Rodríguez and Martínez-Lucio, 2012; Ortega and Marchante, 2010). From 1990 to 2007 the temporary contract rate in Spain remained constantly above $30 \%$ (EC, 2010). In recent years this rate has fallen slightly to around $25 \%$, due in part to the 2006 labor reform (see figure 1). For example, Eurostat figures for 2011 show that the average percentage of employees with a temporary contract in Spain reached $25.3 \%$, whereas the average for the EU-27 was 14.1\%. As regards distribution by sector, table 1 shows that the largest proportion of workers on temporary contracts in Spain is concentrated in the service sector, with a percentage of around $73 \%$ of the total in recent years, whereas in other sectors this percentage is much lower, lying at around $10 \%$ in the industrial sector.

Insert Figure 1

Insert Table 1

In addition, the regulation of the Spanish labor market has also attempted to gradually secure the same working conditions for temporary workers as for permanent employees ${ }^{3}$; however in practice, major differences still remain between the two (Amuedo-Dorantes, 2000; Díaz-Mayans and Sanchez, 2004; ICEDS, 2005; Toharia, 2005). In Spain, temporary work contracts generally offer poorer working conditions than permanent work contracts (AmuedoDorantes, 2002). Most temporary employees contracted by firms typically earn lower wages, have a lower educational level, precarious work, job insecurity, limited development and

\footnotetext{
${ }^{3}$ In general, all the recent labor market reforms contain restrictions on the successive use of temporary contracts, reductions in the cost of firing permanent employees, increases in fiscal support for the creation of jobs with new permanent contracts, and transitory incentives to convert temporary contracts into permanent ones (Ortega and Marchante, 2010).
} 
promotion opportunities and exhibit weaker employment relationships than permanent staff (EC, 2005; ICEDS, 2005; Roca-Puig et al., 2008a; Toharia, 2005). Furthermore, temporary employment in Spain is clearly involuntary and is not an effective vehicle for moving into permanent employment (Amuedo-Dorantes, 2000; Amuedo-Dorantes et al., 2008). The available evidence suggests that temporary posts are subject to high turnover, contradicting the "causality principle" under which temporary contracts are supposed to be used only for transitory needs of firms (EC, 2005; Roca-Puig et al., 2008a; Toharia, 2005). As a result, there is a pronounced segmentation (i.e. dualism) in the Spanish labor market (AmuedoDorantes, 2000; Dolado et al., 2002; Fernández-Rodríguez and Martínez-Lucio, 2012), in line with the core $v s$. peripheral employee model put forward by Atkinson (1984), in which firms make an explicit distinction between the two types of worker according to job tasks and type of contract. While core workers carry out the basic tasks in the organization and enjoy permanent contracts, peripheral employees only carry out accessory tasks and are predominantly hired on a temporary basis.

Despite the speed with which agency work has grown since its emergence in Spain (García-Pérez and Muñoz-Bullón, 2005), most temporary contracts are made directly with the worker, without the intermediary services of a Temporary Help Agency (THA) (De la Calle et al., 2007). THAs offer employment contracts of limited duration to jobseekers and assign them to client firms wishing to hire them to perform jobs of a temporary nature (García-Pérez and Muñoz-Bullón, 2005). Table 2 shows that Spain has a reduced number of agency workers, similar to other EU countries such as Italy, but much lower than the UK. The way this type of work is regulated, whether by legislation or by collective agreements, varies from one country to another depending on each country's traditional labor practice and, in the final instance, explains the differences in growth rates of the agency work industry. In most European Union countries, these firms operate as comprehensive employment agencies; in Spain, however, it 
was not until the recent labor reform Law 3/2012, of February 10, that THAs could operate as private recruitment agencies, managing the entire human resources value chain and working directly with the public employment services. This circumstance may explain the traditional low rate of THA penetration in Spain. Moreover, according to the CIETT (2010), the sectorial distribution of agency work in Europe has seen a recent trend away from usage in the industrial sector (33\% of total agency workers), towards a growing use in the service sector (43\% of total agency workers). In Spain, the use of agency work in the service sector is particularly high (62\%), and is lower in the manufacturing sector (33\%) and other sectors (5\%) such as construction and agriculture (CIETT, 2010). The use of THAs is therefore concentrated in the service sector.

Insert Table 2

\subsection{The benefits and costs of temporary contracts: a curvilinear view}

The literature on labor flexibility highlights the beneficial aspects of temporary hiring for firms through improved temporal adaptation of staff requirements and availabilities to changing conditions in increasingly uncertain markets. Specifically, two types of positive effects are identified: external, through increased revenues; and internal, through reduced labor costs (De Grip and Sieben, 2005; Kleinknecht et al., 2006; Matusik and Hill, 1998; Rodríguez-Gutiérrez, 2007). The external effect occurs when temporary workers are used as a means of accessing valuable knowledge for new services and for high quality products, which is reflected in increased revenues (Broschak and Davis-Blake, 2006; Cardon, 2003; Matusik and Hill, 1998). These highly skilled professionals and technical experts in temporary employment create new and specific knowledge within the organizations that engage them; this knowledge would not otherwise be developed internally, and is especially valuable in 
dynamic and competitive industries. These types of temporary workers enjoy similar work conditions to permanent workers and, consequently, identical (sometimes better) employment relationships with the organizations. The internal effect involves the use of temporary workers as a way to reduce labor costs. Temporary workers may be hired and paid only when there is work to be done (for example, during transitory production peaks), generally earn less than comparable permanent employees and may not be entitled to all the benefits that tenured employees tend to receive from their employers (for example, pension scheme payments or health insurance plans), and can be dismissed more easily and cheaply in adverse circumstances, thus bringing down fixed labor costs (Broschak and Davis-Blake, 2006; Houseman, 2001; Lepak et al., 2003; Michie and Sheehan-Quinn, 2001). External and internal effects may be incompatible, since while the former require highly qualified temporary workers, the latter demand precisely the opposite (Blyton and Morris, 1992; Kleinknecht et al., 2006; Michie and Sheehan-Quinn, 2001). The much higher use of temporary contracts to fill job vacancies that require lower qualifications indicates that Spanish firms have turned to temporary hiring practices essentially as a way of reducing their labor costs (Dolado et al., 2002; ICEDS, 2005; Rodríguez-Gutiérrez, 2007).

At the same time, however, temporary hiring generates costs or disadvantages that undermine firm productivity. Diaz-Mayans and Sánchez (2004) and Bentolila and Dolado (1993) argue that temporary workers may be less efficient than permanent workers, either because of their intrinsic qualities (if they are less capable) or because of their attitude (if they put in less effort). Without doubt, the lower educational level of most temporary workers in Spain and the scant investment in training these workers on the part of firms (EC, 2005; ICEDS 2005) lowers the firm's level of capacity and human capital and, therefore, may decrease labor productivity (Diaz-Mayans and Sánchez, 2004; Rodríguez-Gutiérrez, 2007). Likewise, the poor labor conditions temporary workers face (Amuedo-Dorantes, 2002) lower 
their level of attachment to an organization (Diaz-Mayans and Sánchez, 2004). There is some evidence to suggest that employers' use of temporary employment is due to pressures on labor costs. Forde and Slater (2006) and Houseman (2001) report that although few employers said they used temporary employment in order to save on labor costs (wage, pension, health insurance other social expenditures), employers primarily do make savings by using these arrangements. These employment conditions make it difficult for temporary workers to commit to the organization.

A second disadvantage is the appearance of conflict or tension between temporary and permanent workers that can lessen efficiency among permanent workers (Broschak and Davis-Blake 2006; Davis-Blake et al., 2003; George, 2003). This happens, for instance, when managers increase the permanent workers' responsibilities - by requiring them to supervise temporary workers and take responsibility for their mistakes-without any corresponding remuneration (Davis-Blake et al., 2003); or through increased perception of employment insecurity among permanent workers because on occasions, managers may use temporary workers to send out the message that permanent employees can easily be replaced if their efforts decline, thereby creating a destructive working environment in which permanent workers regard their temporary colleagues as a threat (De Cuyper et al., 2009; Davis-Blake et al., 2003). Similarly, temporary workers speed up the mobility of higher-level permanent employees, while slowing down the mobility of those in lower-level jobs, and weaken the permanent workers' trust in the organization (George, 2003). In the Spanish context, Sánchez and Toharia (2000) report that the presence of temporary workers holds down permanent workers' salary levels, which has a negative effect on their motivation and effort. For all these reasons, permanent workers may view the level of temporary contracts as an indicator of the organization's low-level commitment to them (George, 2003). 
This conflict between temporary and permanent workers only reaches serious levels in firms with a high proportion of temporary contracts (Broschak and Davis-Blake, 2006; De Cuyper et al., 2009; George 2003). The higher the proportion of temporary workers, the greater the negative effect will be. A minimal use of temporary contracts is not expected to strongly influence permanent workers' trust in the organization, but greater magnitudes of temporary contracts can seriously undermine the relationship between organizations and their permanent workers (George, 2003). In particular, De Cuyper et al., (2009) show that the percentage of temporary workers related positively to shared perceptions of job insecurity among permanent workers in Spain. Furthermore, in a firm with a high proportion of temporary contracts, some of their basic activities, the source of their competitive advantage, will probably be carried out by temporary workers. This may cause damage to the firm if the performance of these basic tasks deteriorates significantly when these workers leave, or if it makes imitation by other competitor firms easier (Cardon, 2003; Diaz-Mayans and Sánchez, 2004; Matusik and Hill, 1998). In summary, a high proportion of temporary contracts substantially increases the costs of temporary hiring, and probably outweighs any benefits, thus producing a negative effect of temporary hiring on the firm's results. In contrast, a lower proportion of temporary contracts is more likely to have a positive effect. This conjecture implies that a breakeven point exists, in which the benefits and costs of temporary hiring balance each other out and maximum organizational effectiveness is achieved. Authors such as Cardon (2003), Foote and Folta (2002), Roca-Puig et al., (2008b) and Toharia (2005) have argued that there is a point at which the balance of temporary and permanent workers offers some optimal level of overall firm performance. We thus posit the following hypothesis:

Hypothesis 1. There is a concave downward curvilinear relationship between temporary hiring and organizational outcomes: the higher the proportion of 
temporary contracts, the less positive the effect of temporary hiring on organizational outcomes will be.

\subsection{Direct and indirect temporary hiring}

Although the benefits and costs described above apply to any type of temporary employment, it is useful to distinguish whether the organizations contracting temporary labor services do so via an agency — indirect temporary contracts — or though a direct employment contract - direct temporary contracts. Houseman (2001), Mitlacher (2007), De la Calle et al. (2007) and Muñoz-Bullón and Rodes (2004) argue that indirect temporary hiring entails a further set of advantages for client firms over direct temporary hiring. Firstly, THAs can offer a faster and more efficient service, since they have a database of potential workers who have already been through the selection process. This is a particularly important factor when changing market conditions demand an urgent response and vacancies have to be filled as quickly as possible. Secondly, firms using THAs will save on a series of activities related to selection, follow-up of potential candidates, hiring and training of workers. Thirdly, these intermediary firms represent a professional channel that provides a good match between the job and the worker's capabilities, leading to greater labor productivity for the client firm. Fourthly, THAs continuously promote the experience and employability of the worker, thus generating an efficient combination of practical training and knowledge for the worker with productive results for the client firm. In Spain, Law 29/1999, of June 16, requires THAs to provide theoretical and practical training for the workers they supply to their clients. These investments in training must create skills in the form of general and versatile resources to be used by workers in different contexts. Finally, in Spain the rate with which temporary contracts are made permanent is higher among agency workers than among direct workers (García-Pérez and Muñoz-Bullón, 2005; Muñoz-Bullón and Rodes, 2004), and as such, agency workers are more motivated and make a greater effort in the hope of obtaining a 
permanent job. It may therefore be expected that the higher the proportion of indirect temporary workers, the greater the positive effect of temporary contracts on organizational outcome will be.

Furthermore, Broschak and Davis-Blake (2006) and Davis-Blake et al. (2003) state that temporary workers who are administratively closer to their employers (direct temporary workers) have stronger negative effects on permanent workers than do temporary workers who are more remote in administrative terms (agency temporary workers). Direct temporary hiring gives workers a status of belonging to the firm that is relevant to permanent workers in the processes of social comparison and internal equity. Additionally, permanent employees may have fewer social contacts with agency workers than with direct employees (Houseman et al., 2003). Thus, although there are high turnover rates among workers provided by THAs, the negative consequences on the trust and commitment of the permanent workers are probably moderated. Compared with direct temporary hiring, indirect temporary hiring does not increase the feeling of insecurity among permanent workers to the same extent. It may therefore be expected that the concave downward curvilinear effect will be more intense when direct rather than indirect temporary contracts are used. We therefore posit that:

Hypothesis 2. The higher the proportion of indirect temporary contracts in an organization, the less concave the downward curvilinear relationship between temporary hiring and organizational outcomes will be.

\section{METHODOLOGY}

\subsection{Sample}

To empirically test the theoretical hypotheses put forward, we used the Survey on Business Strategies-Encuesta sobre Estrategias Empresariales (ESEE). Financed by the Spanish Ministry of Industry and Energy, the SEPI (Sociedad Estatal de Participaciones 
Industriales) Foundation is responsible for the Survey's design and administration through the Economic Research Program. The ESEE complements the information from two essential statistical sources that have traditionally been available for analyzing Spanish industry: the Industrial Survey published by the Spanish National Statistics Institute, and the Bank of Spain's Central Balance Sheet Data Office. One of the most relevant characteristics of the ESEE is its representativeness, which means that conclusions drawn from the sample can be claimed as valid for the reference population of Spanish manufacturing firms. Firms were selected on the basis of a combination of exhaustiveness and random sampling criteria ${ }^{4}$.

The reference population for the ESEE is made up of firms with 10 or more workers in manufacturing industries, excluding industrial activities related to oil refining and the treatment of fuels. The geographical area covers the whole of Spain, and all the variables are measured over an annual time frame. In our study, we use data from 2006, the latest period in which the complete survey was carried out. From the original sample of firms, cases with missing data for any of the study variables were eliminated, together with cases with coding errors and non-standard cases that could devalue the information provided for that year, such as firms affected by takeover, merger or separation processes. The final sample used in this study comprised 1,597 firms, of which 423 do not use temporary hiring. Distribution by sector of activity can be seen in Table 3, both through the Standard Industrial Classification system (SIC) and the Spanish National Classification of Economic Activities-Clasificación Nacional de Actividades Económicas (CNAE).

Insert Table 3

\footnotetext{
${ }^{4}$ More detailed information on the Survey on Business Strategies characteristics can be consulted at http://www.funep.es/esee/en/einfo_que es.asp. With some restrictions, the data are publicly available from the SEPI Foundation.
} 


\subsection{Measures}

Control variables. Following the example of studies by Kleinknecht et al. (2006), Lepak et al. (2003) and Michie and Sheehan-Quinn (2001), we selected six control variables. Firm age was calculated as the number of years from the firm's foundation to the time of the survey. Firm size was defined as the logarithm of the average number of employees. The industrial sector was based on the CNAE classification, where 13 sectors of activity were identified. The firm's human capital is the mean of the standardized values of workers' education levels and investment in training. Education level was calculated as the proportion of the workforce that had completed intermediate or higher education. Investment in training was taken as the ratio of expenditure on training to total average number of workers in the firm. Capital intensity was calculated as the ratio of total net fixed assets to average number of employees. Finally, innovation intensity was calculated as the percentage coefficient between R\&D spending and the firm's sales. The calculation and definition of these variables are reported in the annex (Tables I and II).

Independent variables. Similarly to Michie and Sheehan-Quinn (2001) and Roca-Puig et al., (2008a), the temporary hiring level was calculated as the proportion of the workforce employed under temporary contracts in an organization. The proportion of indirect temporary contracts was calculated as the ratio of workers contracted through THAs to the total temporary labor force.

Dependent variables. Datta et al. (2005) advocate focusing on labor productivity to assess organizational outcomes because this indicates the extent to which employees are effectively creating output, and isolates them to a certain extent from external variations in capital and product markets. As in previous studies (e.g., Datta et al., 2005; Matías-Reche, 2003), we use the logarithm of the ratio of sales to employees as a measure of labor productivity. This measure includes the externally generated benefits to the firm of using 
temporary hiring. It does not, however, include internally generated benefits of savings in efficiency, mainly labor costs. It is therefore appropriate to also use a measure of the firm's profitability that covers the overall benefits (external and internal) of using temporary hiring. In this analysis we use the gross operating margin, a measure similar to return on sales (ROS) used in previous studies (e.g., Roca-Puig, et al 2008a).

\section{ANALYSIS AND RESULTS}

Table 4 presents the descriptive statistics and correlations between the study variables. It is worth noting that the average temporary hiring rate of the sample of industrial firms analyzed is $14.4 \%$, evidence of a higher use in Spain than in the European Union as a whole, which had a temporary employment rate in the manufacturing sector of around $9.5 \%$ in 2002 (EC, 2005). We followed Aiken and West's (1991) recommendations in examining our theoretical hypotheses. This involved centering the independent variables to avoid multicollinearity problems between the interaction terms and the variables that constitute them. We used a hierarchical regression analysis to select the model that best accounts for organizational outcomes and to test the hypotheses. Table 5 shows how the introduction of the quadratic term in model 2 for gross operating margin $(-0.083)$ gives rise to a significant change in the explained variance between model 1 and model 2 . The negative sign indicates a concave downward curvilinear relationship between temporary hiring and gross operating margin. Thus hypothesis 1 is confirmed. The effect of temporary hiring on gross operating margin is less positive when the use of temporary contracts is greater. However, hypothesis 1 in not confirmed for labor productivity. Even when the regression coefficient for the quadratic term is negative, it is not significant. Model 1 offers a better explanation of the relationship between temporary contracts and labor productivity, which is revealed as a negative linear relationship (-0.081). Figure 2 shows this relationship. 
Insert Table 4

Insert Table 5

Insert Figure 2

To clarify understanding of the results, Aiken and West (1991) recommend using a figure to illustrate a curvilinear relationship within the range of representative values for the sample of firms analyzed - at one standard deviation below and one above the mean value of the independent variable-. Therefore, in Figure 3 we show the relationship between centered temporary hiring and gross operating margin within the range of values from -0.16 to 0.16 . We can appreciate a predominantly positive concave downward curvilinear relationship between these variables as the maximum of the curve (0.23) - optimal level of temporary contracts - falls outside the meaningful range of the data and a negative relationship does not therefore appear.

Insert Figure 3

To examine hypothesis 2 , we removed the firms that do not use temporary contracts from the initial sample, which left a total of 1,174 firms for this analysis. The average temporary hiring rate of this new sample of industrial firms analyzed is $19.67 \%$ (s.d. 0.158 ) and the mean of the indirect temporary contracts is 0.202 (s.d. 0.323). The Spanish firms' 
preference for direct temporary hiring highlighted by De la Calle et al. (2007) is clearly observed. Table 6 shows a significant change in the explained variance between model 2 and model 3 for gross operating margin ${ }^{5}$. A positive and significant interaction can be seen between the proportion of temporary contracts and that of indirect temporary contracts (0.097), and a positive and significant interaction between temporary contracts squared and the proportion of indirect temporary contracts $(0.176)$. In consequence, the indirect contracts variable is seen to moderate the curvilinearity of the relationship of temporary contracts to gross operating margin. Hypothesis 2 is thus confirmed; that is, the concave downward curvilinear relationship is more pronounced with a low level of proportion of indirect temporary contracts in an organization.

Insert Table 6

In Table 7 and Figure 3 we show the simple regression equations characterizing this curvilinear relationship for low and high values of indirect temporary contracts. According to Aiken and West (1991), this involves dichotomizing the indirect temporary variable, choosing one standard deviation below $(-0.323)$ and one above $(0.323)$ the corresponding mean value. We can observe that when the proportion of indirect temporary contracts is low, the relationship of temporary contracts to gross operating margin is concave downward curvilinear. As indirect temporary contracts increase, this curvilinear relationship changes markedly and becomes a concave upward curvilinear relationship at a high level of indirect temporary contracts. In both cases the turning point-maximum $(-0.020)$ to a concave downward curve and minimum $(-0.109)$ to a concave upward curve - falls within the range of representative values for the firm sample, which enables us to appreciate, respectively, an

\footnotetext{
${ }^{5}$ Results for labor productivity are reported in table 6 for information purposes and to verify that the results do not differ from those obtained when the whole sample is used. Given that previously no curvilinear relationship had been confirmed, there are no grounds, logically, for hypothesis 2 .
} 
inverted U-shaped function and a U-shaped function. All these data provide empirical evidence, as predicted in hypothesis 2 , that the concave downward curvilinear relationship of temporary contracts to gross operating margin is more intense in direct than indirect temporary contracts.

Insert Table 7

\section{CONCLUSION}

Although the curvilinear relationship involves a greater degree of complexity compared with simpler linear paradigms, it enhances and makes a value-added contribution to the theory and practice because it accounts for a wide range of inconsistent and apparently paradoxical findings in the management literature (Pierce and Aguinis, 2013). Based on the labor flexibility literature, this study proposes the existence of a curvilinear relationship between temporary contracts and organizational outcomes. Specifically, we suggest there is a concave downward curvilinear relationship between these two variables, which has a positive effect in firms with a lower proportion of temporary contracts, since the benefits of using these contracts outweigh their costs. In contrast, the costs incurred by firms with a high proportion of temporary contracts outweigh their benefits; this reduces the positive effect and may even lead to a negative effect. This is essentially because a high proportion of temporary contracts in a firm substantially increases the disadvantages or costs of temporary hiring, especially the negative attitudes of permanent workers towards the organization (Broschak and Davis-Blake 2006; De Cuyper et al., 2009; George, 2003; Sanchez and Toharia, 2000). Our study provides partial evidence for this hypothesis, since it is only confirmed when the gross operating margin is considered; in contrast, when examining labor productivity a 
negative linear relationship emerges. Moreover, within the range of representative values of the firm sample analyzed a predominantly positive concave downward curve is seen between temporary contracts and gross operating margin; in other words, even when we consider a high use of temporary contracts a negative relationship does not emerge. Consequently, in contrast to the positions held by Cardon (2003), Foote and Folta (2002) and Toharia (2005), we do not find that there is an optimal proportion of temporary contracts that maximizes organizational outcomes. This curve does not have a point of inflection.

Otherwise, we can see how an increase in temporary hiring raises gross operating margin, but at the same time reduces labor productivity. This seems to point to a certain conflict of objectives. From a managerial point of view, the final decision will probably depend to some extent on the competitive strategy the firm pursues (Michie and SheehanQuinn, 2001). Firms with an aggressive position and whose basic competitive priority is to increase their market share, even at the expense of lower efficiency, should consider reducing their proportion of temporary contracts. In contrast, if they pursue a defensive position in which their basic competitive priority is to minimize costs, even at the expense of a decline in market share, it would be more appropriate to increase their temporary contract rate.

Likewise, given that the measure of labor productivity represents the external effectthrough income — of temporary hiring, and the gross operating margin represents the overall effect (external and internal), we can infer from the difference observed between the two that the main advantage firms obtain through the use of temporary contracts is in substantial savings in labor costs. This finding coincides with previous studies (e.g., Kleinknecht et al., 2006; Rodríguez-Gutiérrez, 2007) in which the use of temporary contracts leads to savings on wage bills, but does not translate into higher sales. Consequently, in Spain the difference between severance payments for temporary and permanent workers is known to be high, and this is the key to understanding the success of temporary contracts (Díaz-Mayans and Sanchez, 
2004; Dolado et al., 2002; ICEDS, 2005). Similarly, results show that the internal and external effects of temporary hiring are incompatible, as they substitute one another (Blyton and Morris, 1992; Kleinknecht et al., 2006; Michie and Sheehan-Quinn, 2001). The positive link to labor cost savings may explain the use of temporary contracts by some employers, but may be to the detriment of other aspects of firm performance, such as sales. It therefore comes as no surprise that most temporary employees contracted by Spanish firms typically earn low wages, have a low educational level, work in precarious conditions, and that temporary employment is not used to screen for movement into permanent employment (AmuedoDorantes, 2001; Diaz-Mayans and Sánchez, 2004). These characteristics make it difficult to capitalize on the advantages (i.e. external effect) of using temporary employment foreseen by Cardon (2003), Houseman (2001) and Matusik and Hill (1998).

From the comparative analysis between the direct and indirect forms of temporary hiring, firstly we show that the concave downward curvilinear relationship between temporary contracts and gross profit margin is increasingly manifested as the proportion of indirect contracts decreases. When the proportion of indirect temporary contracts is low the relationship of temporary contracts to gross operating margin is concave downward curvilinear. As the proportion of indirect temporary contracts increases, the relationship of temporary contracts to gross operating margin becomes concave upward curvilinear. In both scenarios, a point of inflection is seen and a negative relationship coexists with a positive relationship. This result provides evidence that the curvilinear relationship between temporary contracts and organizational outcomes differs according to the proportion of temporary agency employment in relation to direct-hire temporaries.

We can appreciate that the concave downward curvilinear relationship is typical of firms that mainly use direct hiring arrangements, and is not found in firms that use indirect hiring. Only in the case of high direct temporary contract use, and when the gross operating 
margin is analyzed as a dependent variable, our results support the arguments of Broschak and Davis-Blake (2006), Cardon (2003), Foote and Folta, (2002), George (2003) and RocaPuig et al., (2008b) in that the excessive use of temporary contracts by a firm leads to a sharp decline in its organizational outcomes, and a negative relationship thus appears. As we can see in Figure 3, the maximum of the curve falls within the range of representative values for the firm sample analyzed. Consequently, in this context, we can find an optimal proportion of temporary contracts that maximizes organizational outcomes. Finally, the figure also shows that in a context of high temporary hiring, the claim made by Houseman (2001) and MuñozBullón and Rodes (2004) becomes particularly relevant, namely that firms using the indirect temporary hiring approach obtain a higher level of organizational outcomes than those hiring temporary workers directly. Intermediation by THAs brings additional advantages to user firms as compared to firms that take on the task of hiring temporary workers themselves (Broschak and Davis-Blake, 2006; Houseman et al., 2003; Mitlacher, 2007). Given the high rate of temporary hiring in Spain, and the fact that Spanish firms use direct hiring more than other methods, they are seen to be missing out on the advantages that temporary workers supplied by THAs bring (De la Calle et al., 2007). Our results suggest that Spanish companies should substitute direct-hire temporaries for agency temporaries if they use temporary workers intensively. In this context, the claim made by various public and private institutions (e.g., the Spanish government, CIETT) that THAs are effective and efficient agents to revitalize the labor market and contribute to improving firms' competitiveness appears to be particularly valid.

The high rate of temporary hiring in Spain means that our results are limited to the Spanish context. We need to understand issues of labor flexibility within existing national institutional frameworks (Blyton and Martínez-Lucio, 1995). It would therefore be interesting to replicate this investigation in other countries with different rates of temporary hiring, 
conducting comparative studies, such as that of Tregaskis and Brewster (2006), which assess the convergence or divergence of the impact of temporary contracts on firms' efficacy in different countries. Similarly, it should be highlighted that our empirical results are limited to the manufacturing sector. Future research could be carried out in other economic activities, such as services sector subject to large seasonal and cyclical demand fluctuations with a higher rate of temporary employment (EC, 2005; Houseman, 2001), where a more acute concave downward curvilinear relationship between temporary contracts and labor productivity may be expected. Likewise, THAs have a greater rate of penetration in the services sector, which could affect the results of analyses comparing indirect and direct temporary contracts.

In addition, this study was conducted exclusively at the organizational level. Future research in the field of labor flexibility could usefully adopt a multilevel approach, by integrating the individual and organizational levels that have been considered as separate approaches. Studies focusing on the individual level (e.g., De Cuyper et al., 2009; Mauno et al., 2012), originating from the field of psychology, set out to demonstrate the influence of certain behaviors and attitudes held by temporary workers about their work performance, but neglect the organizational context in which these processes take place. Studies focusing on the organization (e.g., Lepak et al. 2003; Valverde et al. 2000), grounded on economic approaches, explore the influence of this employment mode on organizational outcomes, without taking into account the essential role of employees as a critical organizational resource to explain this relationship. Integrating the two perspectives could contribute to advancing the field of human resource management (Ostroff and Bowen, 2000). Lastly, it should be noted that our empirical analyses only estimate relationships between the independent and dependent variables, but do not indicate any causality. 


\section{REFERENCES}

Aiken, Leona. S., and Stephen G. West. 1991. "Multiple Regression: Testing and Interpreting Interactions.” Sage Publications, Newbury Park.

Amuedo-Dorantes, Catalina, Miguel A. Malo, and Fernando Muñoz-Búllon. 2008. "The role of temporary help agency employment on Temp-to-Perm transitions." Journal of Labor Research, Vol. 29, pp. 138-161.

Amuedo-Dorantes, Catalina. 2000. "Work transitions into and out of involuntary temporary employment in a segmented market: evidence from Spain.” Industrial and Labor Relations Review, Vol. 53, No. 2, pp. 309-325.

Amuedo-Dorantes, Catalina. 2002. "Work safety in the context of temporary employment: the Spanish experience.” Industrial and Labor Relations Review, Vol. 55, No. 2, pp. $262-$ 285.

Atkinson, J. 1984. "Manpower strategies for flexible organizations.” Personnel Management, Vol. 16, No. 8, pp. 28-31.

Bentolila, Samuel, and Juan J. Dolado. 1993. “La contratación temporal y sus efectos sobre la competitividad." Papeles de Economía Española, No. 56, pp. 112-130.

Blyton, Paul, and Jonathan Morris. 1992. "HRM and the limits of flexibility", in Blyton, P. and Turnbull, P. (Eds.) Reassessing Human Resource Management, Sage Publications, London, pp. 116-130.

Blyton, Paul, and Miguel Martínez-Lucio, M. 1995. "Industrial relations and the management of flexibility: factors shaping developments in Spain and the United Kingdom." International Journal of Human Resource Management, Vol. 6, pp. 271-291.

Broschak, Joseph P., and Alison Davis-Blake. 2006. "Mixing standard work and nonstandard deals: the consequences of heterogeneity in employment arrangement", Academy of Management Journal, Vol. 49, No. 2, pp. 371-393. 
Cardon, Melissa S. 2003. "Contingent labor as an enabler of entrepreneurial growth." Human Resource Management, Vol. 42, No. 4, pp. 357-373.

CIETT (International Confederation of Private Employment Agencies). 2010. "The agency work industry around the world." Economic report.

Datta, Deepak, James P. Guthrie, and Patrick M. Wright. 2005. "Human resource management and labor productivity: does industry matter?" Academy of Management Journal, Vol 48, pp. 135-145.

Davis-Blake, Alison, Joseph P. Broschak, and Elizabeth George. 2003. "Happy together? How using non-standard workers affects exit, voice, and loyalty among standard employees.” Academy of Management Journal, Vol 46, No. 4, pp. 475-485.

De Cuyper, Nele, and Hans De Whitte. 2007. “Associations between contract preference and attitudes, well-being and behavioral intentions of temporary workers." Economic and Industrial Democracy, Vol. 28, No. 2, pp. 292-312.

De Cuyper, Nele, Beatriz Sora, Hans De Whitte, Amparo Caballer, and José M Peiró. 2009. “Organizations' use of temporary employment and a climate of job insecurity among Belgian and Spanish permanent workers." Economic and Industrial Democracy, Vol. 30, pp. 564-591.

De Cuyper, Nele, Jeroen De Jong, Hans De Witte, Kerstin Isaksson, Thomas Rigotti, and René Schalk. 2008. "Literature review of theory and research on the psychological impact of temporary employment: Towards a conceptual model." International Journal of Management Reviews, Vol. 10, pp. 25-51.

De Grip, Andries, and Inge Sieben. 2005. "The effects of human resource management on small firms' productivity and employees' wages." Applied Economics, Vol. 37, No. 9, pp. 1047-1054. 
De la Calle, Carmen, Marta Ortiz, and Marta Romero. 2007. "La intermediación de las empresas de trabajo temporal y el mercado laboral español", in Ayala J.J. (ed.) “Conocimiento, innovación y emprendedores: camino al futuro", Universidad de la Rioja, Logroño, pp. 2675-2687.

Diaz-Mayans, Maria A., and Rosario Sánchez. 2004. "Temporary employment and technical efficiency in Spain.” International Journal of Manpower, Vol. 25, No. 2, pp. 181-194.

Dolado, Juan J., Carlos García-Serrano, and Juan F. Jimeno. 2002. "Drawing lessons from the boom of temporary jobs in Spain.” The Economic Journal, No. 112, pp. 270-295.

EC (European Commission). 2005. "Employment in Europe 2005. Recent Trends and Prospects", European Communities, Belgium.

EC (European Commission). 2010. “Employment in Europe 2010.” European Communities, Belgium.

Fernández-Rodríguez, Carlos J., and Miguel Martínez-Lucio. 2012. "Narratives, myths and prejudice in understanding employment systems: The case of rigidities, dismissals and flexibility in Spain." Economic and Industrial Democracy, DOI: $10.1177 / 0143831 X 12445625$.

Foote, David A., and Timothy B. Folta. 2002. "Temporary workers as real options." Human Resource Management Review, Vol. 12, pp. 579-597.

Forde, C. and Slater, G. 2006. "The nature and experience of agency working in Britain. What are the challenges for human resource management?” Personnel Review, Vol. 35, pp. $141-157$.

García-Pérez, Ignacio, and Fernando Muñoz-Bullón 2005. “Temporary help agencies and occupational mobility." Oxford Bulletin of Economics and Statistics, Vol. 67, No. 2, pp. $163-180$. 
George, Elizabeth. 2003. "External solutions and internal problems: the effects of employment externalization on internal workers' attitudes.” Organization Science, Vol. 14, No. 4, pp. 386-402.

Houseman, Susan N. 2001. "Why employers use flexible staffing arrangements: evidence from an establishment survey." Industrial and Labor Relations Review, Vol. 55, No. 1, pp. 149-170.

Houseman, Susan N., Arne L. Kalleberg, and George A. Erickced. 2003. "The role of temporary agency employment in tight labor markets.” Industrial and Labor Relations Review, Vol. 57, No. 1, pp. 105-127.

ICEDS (Informe de la Comisión de Expertos para el Diálogo Social) (2005): “Más y mejor empleo en un nuevo escenario socioeconómico. Por una flexibilidad y seguridad laborales efectivas”, Ministerio de Trabajo y Asuntos Sociales, Madrid.

Kalleberg, Arn L. 2001. "Organizing flexibility: The flexible firm in a new century”, British Journal of Industrial Relations, Vol. 39, pp. 479-504.

Kleinknecht, Alfred, Remco M. Oostendorp, Menno Pradhan, and C.W.M. Naastepad (2006): "Flexible labour, firm performance and the Dutch job creation miracle." International Review of Applied Economics, Vol. 20, No. 2, pp. 171-187.

Lepak, David P., Riki Takeuchi, and Scott A. Snell. 2003. "Employment flexibility and firm performance: examining the interaction effects of employment mode, environmental dynamism, and technological intensity." Journal of Management, Vol 29, No. 5, pp. 681-703.

Lozza, Eduardo, Chiara Libreri, and Albino C. Bosio. 2013. "Temporary employment, job insecurity and their extraorganizational outcomes." Economic and Industrial Democracy, Vol. 34, No. 1, pp. 89-105. 
Matías-Reche, Fernando. 2003. "The size and environment entrepreneurial. Effect on the use of temporary help agencies and the labor productivity." Revista Europea de Dirección y Economía de la Empresa, Vol. 12, No. 1, pp. 217-232.

Matusik, Sharon F., and Charles W.L. Hill. 1998. "The utilization of contingent work, knowledge creation, and competitive advantage." Academy of Management Review, Vol. 23, No. 4, pp. 680-697.

Mauno, Saija, De Cuyper, Nele, Ulla Kinnunen, and Hans De Witte. 2012. "Work characteristics in long-term temporary workers and temporary-to-permanent workers: A prospective study among Finnish health care personnel." Economic and Industrial Democracy, Vol. 33, No. 3, pp. 357-377.

McIlroy, Rachael, Paul Marginson, and Ida Regalia. 2004. "Regulating external and internal forms of flexibility at local level: Five European regions compared", International Journal of Human Resource Management, Vol. 15, No. 2, pp. 295-313.

Michie, Jonathan, and Maura Sheehan-Quinn. 2001. "Labour Market Flexibility, Human Resource Management and Corporate Performance." British Journal of Management, Vol. 12, pp. 287-306.

Mitlacher, Lars W. 2007. "The role of temporary agency work in different industrial relations systems - a comparison between Germany and the USA.” British Journal of Industrial Relations, Vol. 45, No. 3, pp. 581-606.

Muñoz-Bullón, Fernando, and Eduardo C. Rodes. 2004. “Temporalidad y señalización en el mercado de trabajo: el papel de las empresas de trabajo temporal." Cuadernos de Economía y Dirección de la Empresa, Vol. 18, No. 1, pp. 35-67.

Ortega, Bienbenido, and Andrés J. Marchante. 2010. “Temporary contracts and labour productivity in Spain: a sectoral analysis.” Journal of Productivity Analysis, Vol. 34, No. 3, pp. 199-212. 
Ostroff, Cheri, and David E. Bowen. 2000. Moving human resource to a higher level. Human resource practices and organizational effectiveness. In Klein, Katherine J., and Steve W.J. Kozlowski (eds.), Multi-level Theory, Research, and Methods in Organizations, San Francisco, CA: Jossey-Bass, pp.211-266.

Pierce, Jason R, and Herman Aguinis. 2013. "The too-much-of-a-good-thing effect in management.” Journal of Management, Vol. 39, No. 2, pp. 313-338.

Roca-Puig, Vicente, Inmaculada Beltrán-Martín, Juan C. Bou-Llusar, and Ana B. Escrig-Tena. 2008a. "External and internal labour flexibility in Spain: a substitute or complementary effect on firm performance?" International Journal of Human Resource Management, Vol. 19, No. 6, pp. 1133-1153.

Roca-Puig, Vicente, Inmaculada Beltrán-Martín, Juan C. Bou-Llusar, Ana B. Escrig-Tena, and Mercedes Segarra-Ciprés. 2008b. "In search of the optimal proportion of temporary contracts in the Spanish industry." Universia Business Review, Vol. 19, pp. 84-99.

Rodríguez-Gutiérrez, César. 2007. "Effects of temporary hiring on the profits of Spanish manufacturing firms." International Journal of Manpower, Vol. 28, No. 2, pp. 152174.

Sánchez, Rosario, and Luis Toharia. 2000. "Temporary workers and productivity: the case of Spain”, Applied Economics, No. 32, pp. 583-591.

Silla, Inmaculada, Francisco J. Gracia, and José M. Peiró. 2005. “Job insecurity and heathrelated outcomes among different types of temporary workers." Economic and Industrial Democracy, Vol. 26, No. 1, pp. 89-117.

Toharia, Luis. 2005. “El problema de la temporalidad en España: un diagnóstico”, Ministerio de Trabajo y Asuntos Sociales, Madrid. 
Tregaskis, Olga, and Brewster, Chris. 2006. "Converging or diverging? A comparative analysis of trends in contingent employment practice in Europe over a decade." Journal of International Business Studies, Vol. 37, pp. 111-126.

Valverde, Mireia, Olga Tregaskis, and Chris Brewster. 2000. "Labor flexibility and firm performance." International Advances in Economic Research, Vol. 6, No. 4, pp. 649661. 


\section{ANNEX}

Table I. Variable calculations

\begin{tabular}{ll}
\hline Variables & Mathematical functions \\
\hline Firm age & 2006 - AEMP \\
Firm size & Lg (PNEM + EVENME + PERETT) \\
Sectors of activity & NACECLIO \\
Innovation intensity & IDV \\
Human capital & Mean [standardized (GEFT / (PNEM + EVENME + PERETT)), standardized (100 - PNT) \\
Capital intensity & IN / (PNEM + EVENME + PERETT) \\
Proportion of temporary contracts & (EVENME + PERETT) / (PNEM + EVENME + PERETT) \\
Proportion of indirect temporary contracts & PERETT / (EVENME + PERETT) \\
Labor productivity & Lg (PBSOI / (PNEM + EVENME + PERETT)) \\
Gross operating margin & MBE \\
\hline
\end{tabular}

Note: ${ }^{a}$ Advice was sought from the SEPI Foundation on these calculations, particularly those relating to the number of workers. The total labor force of the manufacturing firms (firm size) was calculated in full-time equivalents, taking into account the variability and duration of the temporary contract (i.e., when temporary workers are only employed for a few months). The innovation intensity and gross operating margin variables were calculated by the SEPI Foundation directly. 
Table II. Identification of the ESEE variables ${ }^{a}$

\begin{tabular}{ll}
\hline \multicolumn{1}{c}{ ESEE Code } & \multicolumn{1}{c}{ Definition } \\
\hline AEMP & Year the firm was created. \\
EVENME & Average number of casual workers. ${ }^{b}$ This is calculated as the simple mean \\
& of the casual workers in each quarter, when this number has changed \\
& significantly, or is based on the number of casual workers at the end of the \\
& year when the company reports that this number has not changed \\
& significantly. \\
& Average number of workers supplied by temporary agencies. \\
PERETT & Average number of regular workers. This is calculated by identifying the \\
PNEM & average of non-casual personnel at the end of the previous year and at the \\
& end of the current year. When the regular workforce experienced \\
& significant changes during the year, the regular workforce used is the \\
& average at the end of each quarter adjusted for the presence of part-time \\
& workers. \\
& Firm's main activity. \\
Percentage of sales volume represented by total R\&D expenditure. \\
IDV & Total net fixed assets. \\
TN & Total value of external expenditure on employee training. \\
GEFT & Percentage of total personnel represented by non-graduate personnel. \\
PBSOI & Production and other incomes. Total sales, the variation in stocks for sale \\
aBd other current management income. & Gross operating margin. Firm's profitability, defined as the percentage of \\
& total sales plus their variation in stocks and other current management \\
& income represented by total sales, variation in stocks and other current \\
& management income minus purchases, external services and labor costs. \\
\hline &
\end{tabular}

Notes:

${ }^{a}$ We used the original codes and definitions provided by the SEPI Foundation in order to facilitate understanding of the variables included in the study.

${ }^{b}$ Temporary workers supplied by THAs are not included.

$c$ An equivalent calculation is to divide the number of hours all THA employees work in the year by the normal annual working hours of an employee in the firm as stipulated by agreements or legislation. These two variables also appear in the ESEE. 
Table 1. Distribution of Spanish temporary workers by economic activity, 2008-2012. (Units: 1000 workers)

\begin{tabular}{cccccc}
\hline Activity & 2012 & 2011 & 2010 & 2009 & 2008 \\
\hline Total & 3364.6 & 3489.4 & 3621.5 & 3745.6 & 3825.9 \\
Agriculture & 254.9 & 251.7 & 250.1 & 248.1 & 248.8 \\
Industry & 351.9 & 357.4 & 364.5 & 373.7 & 383.9 \\
Construction & 291.0 & 316.3 & 347.3 & 380.0 & 419.6 \\
Services & 2466.9 & 2564.0 & 2659.8 & 2744.0 & 2773.7 \\
\hline
\end{tabular}

Source: Encuesta de Población Activa (EPA), National Statistics Institute (INE)

Table 2. European agency work penetration rates by countries, 2004-2008.

\begin{tabular}{clllll}
\hline Country & 2008 & 2007 & 2006 & 2005 & 2004 \\
\hline France & $2.3 \%$ & $2.5 \%$ & $2.4 \%$ & $2.4 \%$ & $2.4 \%$ \\
Germany & $2.0 \%$ & $1.6 \%$ & $1.3 \%$ & $1.0 \%$ & $0.9 \%$ \\
Italy & $0.9 \%$ & $1.0 \%$ & $0.7 \%$ & $0.7 \%$ & $0.7 \%$ \\
The Netherlands & $2.9 \%$ & $2.8 \%$ & $2.5 \%$ & $2.2 \%$ & $1.9 \%$ \\
Spain & $0.7 \%$ & $0.8 \%$ & $0.7 \%$ & $0.7 \%$ & $0.7 \%$ \\
United Kingdom & $4.1 \%$ & $4.8 \%$ & $4.5 \%$ & $4.3 \%$ & $4.2 \%$ \\
\hline
\end{tabular}

Source: International Confederation of Private Employment Agencies (CIETT, 2010)

Note: The penetration rate of agency work describes the number of agency workers (full time equivalent) in relation to the country's total workforce. 
Table 3. Distribution of firms by sectors of activity $(N=1,597)$

\begin{tabular}{llcc}
\hline \multicolumn{1}{c}{ SIC } & \multicolumn{1}{c}{ CNAE } & Number & Percentage \\
\hline 20 and 21 & DA. Food, drink and tobacco industry & 201 & $12.59 \%$ \\
22 and 23 & DB. Textile and clothing industry & 130 & $8.14 \%$ \\
31 & DC. Leather and footwear industry & 42 & $2.63 \%$ \\
24 and 25 & DD. Timber and cork industry & 59 & $3.69 \%$ \\
26 and 27 & DE. Paper industry; publishing, graphic arts and reproduction of engravings & 138 & $8.64 \%$ \\
28 & DG. Chemical industry & 106 & $6.64 \%$ \\
30 & DH. Rubber transformation and plastic materials industry & 80 & $5.01 \%$ \\
32 & DI. Other mineral, non-metallic product industries & 122 & $7.64 \%$ \\
33 and 34 & DJ. Primary metal industry and manufacturing of metal products & 264 & $16.53 \%$ \\
35 and 36 & DK. Machinery and electrical equipment manufacturing industry & 113 & $7.08 \%$ \\
38 & DL. Electrical, electronic and optical materials and equipment industry & 114 & $7.14 \%$ \\
37 & DM. Manufacturing of transportation equipment industry & 118 & $7.39 \%$ \\
39 & DN. Miscellaneous manufacturing industries & 110 & $6.89 \%$ \\
\hline
\end{tabular}


Table 4. Descriptive statistics and correlations $(N=1,597)$

\begin{tabular}{|c|c|c|c|c|c|c|c|c|c|c|}
\hline Variables & Mean & s.d. & 1 & 2 & 3 & 4 & 5 & 6 & 7 & 8 \\
\hline 1. Firm age & 27.924 & 20.804 & 1 & & & & & & & \\
\hline 2. Firm size $(\log )$ & 1.856 & 0.639 & $0.339^{* * *}$ & 1 & & & & & & \\
\hline 3. Innovation intensity & 0.762 & 2.230 & $0.070^{* * *}$ & $0.185^{* * *}$ & 1 & & & & & \\
\hline 4. Human capital & 0.000 & 0.738 & $0.137^{* * *}$ & $0.229^{* * *}$ & $0.245^{* * *}$ & 1 & & & & \\
\hline 5. Capital intensity & 62374.7 & 117078.6 & $0.145^{* * *}$ & $0.267^{* * *}$ & 0.028 & $0.181^{* * *}$ & 1 & & & \\
\hline 6. Temporary contracts & 0.144 & 0.160 & $-0.124^{* * *}$ & $0.107^{* * *}$ & -0.009 & -0.042 & $-0.054^{* *}$ & 1 & & \\
\hline 7. Labor productivity $(\log )$ & 5.106 & 0.356 & $0.233^{* * *}$ & $0.497^{* * *}$ & $0.084^{* * *}$ & $0.283^{* * *}$ & $0.443^{* * *}$ & -0.047 & 1 & \\
\hline 8. Gross operating margin & 8.041 & 13.294 & 0.008 & 0.034 & 0.028 & $0.094^{* * * *}$ & $0.118^{* * *}$ & 0.032 & $0.220^{* * * *}$ & 1 \\
\hline
\end{tabular}

Note: $* * * p<0.01 ; * * p<0.05$ (two-tailed) 
Table 5. Results of hierarchical regression analyses $(N=1,597)$

\begin{tabular}{|c|c|c|c|c|}
\hline \multirow[t]{2}{*}{ Variables } & \multicolumn{2}{|c|}{ Labor productivity } & \multicolumn{2}{|c|}{ Gross operating margin } \\
\hline & Model 1 & Model 2 & Model 1 & Model 2 \\
\hline Firm age & 0.031 & 0.031 & -0.011 & -0.009 \\
\hline Firm size & $0.363^{* * *}$ & $0.362^{* * *}$ & -0.013 & -0.025 \\
\hline Food, drink and tobacco industry & 0.019 & 0.019 & 0.016 & 0.016 \\
\hline Textile and clothing industry & $-0.206^{* * *}$ & $-0.205^{* * *}$ & $-0.096^{* *}$ & $-0.091^{* *}$ \\
\hline Leather and footwear industry & $-0.049^{* *}$ & $-0.049^{* *}$ & -0.019 & -0.017 \\
\hline Timber and cork industry & $-0.066^{* * *}$ & $-0.066^{* * *}$ & -0.033 & 0.033 \\
\hline Paper industry & $-0.055^{* *}$ & $-0.055^{* *}$ & $0.062^{* *}$ & $0.064^{* *}$ \\
\hline Chemical industry & $0.045^{* *}$ & $0.046^{* *}$ & -0.020 & -0.016 \\
\hline Rubber transformation and plastic industry & $-0.054^{* *}$ & $-0.054^{* *}$ & 0.014 & 0.014 \\
\hline Other mineral, non-metallic product industries & $-0.046^{* *}$ & $-0.047^{* *}$ & 0.020 & 0.019 \\
\hline Machinery and electrical equipment manufacturing industry & -0.027 & -0.026 & -0.004 & -0.002 \\
\hline Electrical, electronic, optical and equipment industry & $-0.037^{*}$ & $-0.037^{*}$ & 0.016 & 0.017 \\
\hline Manufacturing of transportation equipment industry & -0.009 & -0.009 & $-0.074^{* *}$ & $-0.071^{* *}$ \\
\hline Miscellaneous manufacturing industries & $-0.094^{* * *}$ & $-0.094^{* * *}$ & -0.015 & -0.014 \\
\hline Innovation intensity & $-0.038^{*}$ & $-0.038^{* *}$ & 0.023 & 0.019 \\
\hline Human capital & $0.108^{* * *}$ & $0.108^{* * *}$ & $0.068^{* *}$ & $0.067^{* *}$ \\
\hline Capital intensity & $0.287^{* * *}$ & $0.287^{* * *}$ & $0.100^{* * *}$ & $0.102^{* * *}$ \\
\hline Temporary contracts & $-0.081^{* * *}$ & $-0.076^{* * *}$ & $0.044^{*}$ & $0.106^{* * *}$ \\
\hline Temporary contracts squared & & -0.007 & & $-0.083^{* *}$ \\
\hline$R^{2}\left(\Delta R^{2}\right)$ & 0.424 & $0.424(0.000)$ & 0.044 & $-0.047(0.003)^{* *}$ \\
\hline$F$ & $64.569^{* * *}$ & $61.137^{* * *}$ & $4.001^{* * *}$ & $4.082^{* * * *}$ \\
\hline
\end{tabular}

Note: Standardized regression coefficients $* * * p<0.01 ; * *<0.05 ; * p<0.10$ (two-tailed) 
Table 6. Results of hierarchical regression analyses $(N=1,174)$

\begin{tabular}{|c|c|c|c|c|c|c|}
\hline \multirow[t]{2}{*}{ Variables } & \multicolumn{3}{|c|}{ Labor productivity } & \multicolumn{3}{|c|}{ Gross operating margin } \\
\hline & $\begin{array}{l}\text { Model } 1 \\
0.025\end{array}$ & $\begin{array}{l}\text { Model } 2 \\
0.025\end{array}$ & $\begin{array}{l}\text { Model } 3 \\
0.023\end{array}$ & $\begin{array}{c}\text { Model } 1 \\
-0.009\end{array}$ & $\begin{array}{c}\text { Model } 2 \\
-0.008\end{array}$ & $\begin{array}{l}\text { Model } 3 \\
-0.005\end{array}$ \\
\hline $\begin{array}{l}\text { Firm age } \\
\text { Firm size }\end{array}$ & $0.356^{* * *}$ & $0.356^{* * * *}$ & $0.356^{* * *}$ & -0.034 & -0.034 & -0.038 \\
\hline Food, drink and tobacco industry & 0.040 & 0.040 & 0.039 & 0.029 & 0.030 & 0.027 \\
\hline Textile and clothing industry & $-0.177^{* * *}$ & $-0.177^{* * * *}$ & $-0.177^{* * *}$ & $-0.075^{* *}$ & $-0.069^{* *}$ & $-0.070^{*}$ \\
\hline Leather and footwear industry & -0.010 & -0.010 & -0.009 & -0.028 & -0.026 & -0.025 \\
\hline Timber and cork industry & $-0.047^{* *}$ & $-0.047^{* *}$ & $-0.048^{* *}$ & -0.024 & -0.024 & -0.022 \\
\hline Paper industry & $-0.045^{*}$ & $-0.045^{*}$ & $-0.044^{*}$ & $0.123^{* * *}$ & $0.126^{* * *}$ & $0.119^{* * * *}$ \\
\hline Chemical industry & $0.046^{*}$ & $0.046^{*}$ & $0.047^{*}$ & -0.003 & -0.003 & -0.001 \\
\hline Rubber transformation and plastic industry & $-0.056^{* *}$ & $-0.056^{* *}$ & $-0.057^{* *}$ & 0.027 & 0.026 & 0.022 \\
\hline Other mineral, non-metallic product industries & $-0.052^{* *}$ & $-0.052^{* *}$ & $-0.050^{* *}$ & 0.052 & 0.051 & 0.049 \\
\hline Machinery and electrical equipment manufacturing industry & -0.002 & -0.002 & -0.005 & -0.028 & -0.031 & 0.026 \\
\hline Electrical, electronic, optical and equipment industry & -0.034 & -0.034 & -0.039 & 0.022 & 0.024 & 0.023 \\
\hline Manufacturing of transportation equipment industry & 0.008 & 0.008 & 0.008 & -0.041 & -0.039 & -0.040 \\
\hline Miscellaneous manufacturing industries & $-0.078^{* * *}$ & $-0.078^{* * * *}$ & $-0.078^{* * *}$ & -0.013 & -0.010 & -0.010 \\
\hline Innovation intensity & $-0.053^{* *}$ & $-0.053^{* *}$ & $-0.054^{* *}$ & 0.007 & 0.004 & 0.008 \\
\hline Human capital & $0.086^{* * *}$ & $0.086^{* * *}$ & $0.086^{* * *}$ & $0.062^{*}$ & $0.062^{*}$ & $0.059^{*}$ \\
\hline Capital intensity & $0.325^{* * *}$ & $0.325^{* * *}$ & $0.326^{* * * *}$ & $0.101^{* * *}$ & $0.103^{* * *}$ & $0.106^{* * *}$ \\
\hline Proportion indirect contracts & $0.086^{* * *}$ & $0.086^{* * * *}$ & $0.121^{* * * *}$ & $-0.052^{*}$ & -0.046 & -0.064 \\
\hline Temporary contracts & $-0.075^{* * *}$ & $-0.075^{* *}$ & $-0.081^{* *}$ & 0.008 & 0.066 & $0.093^{* *}$ \\
\hline Temporary contracts squared & & 0.001 & -0.043 & & $-0.077^{*}$ & 0.088 \\
\hline Temporary contracts $\mathrm{x}$ proportion indirect contracts & & & 0.013 & & & $0.097^{* *}$ \\
\hline Temporary contracts squared x proportion indirect contracts & & & -0.069 & & & $0.176^{* *}$ \\
\hline$R^{2}\left(\Delta R^{2}\right)$ & 0.479 & $0.479(0.000)$ & $0.480(0.001)$ & 0.051 & $0.054(0.003)^{*}$ & $0.062(0.008)^{* *}$ \\
\hline$F$ & $55.909^{* * *}$ & $53.067^{* * *}$ & $48.340^{* * *}$ & $3.291^{* * *}$ & $3.306^{* * *}$ & $3.437^{* * *}$ \\
\hline
\end{tabular}

Note: Standardized regression coefficients $* * * p<0.01 ; * * p<0.05 ; * p<0.10$ (two-tailed) 
Table 7. Simple regression equations of the effect of temporary contracts $(X)$ on gross operating margin $(Y)$

\begin{tabular}{c|l}
\hline$N=1,597($ Model 2$)$ & \multicolumn{1}{c}{$N=1,174($ Model 3$)$} \\
\hline$Y=-18.901^{* *} X^{2}+8.729^{* * *} X+9.213$ & $\begin{array}{l}\text { High indirect contracts: } Y=66.423^{* *} X^{2}+14.535^{* * *} X+8.231 \\
\text { Low indirect contracts: } Y=-30.645^{* *} X^{2}-1.255 X+9.679\end{array}$ \\
\hline
\end{tabular}

Note: Unstandardized regression coefficients $* * * p<0.01 ; * * p<0.05 ; * p<0.10$ (two-tailed) 
Figure 1. Temporary work in selected European Union countries

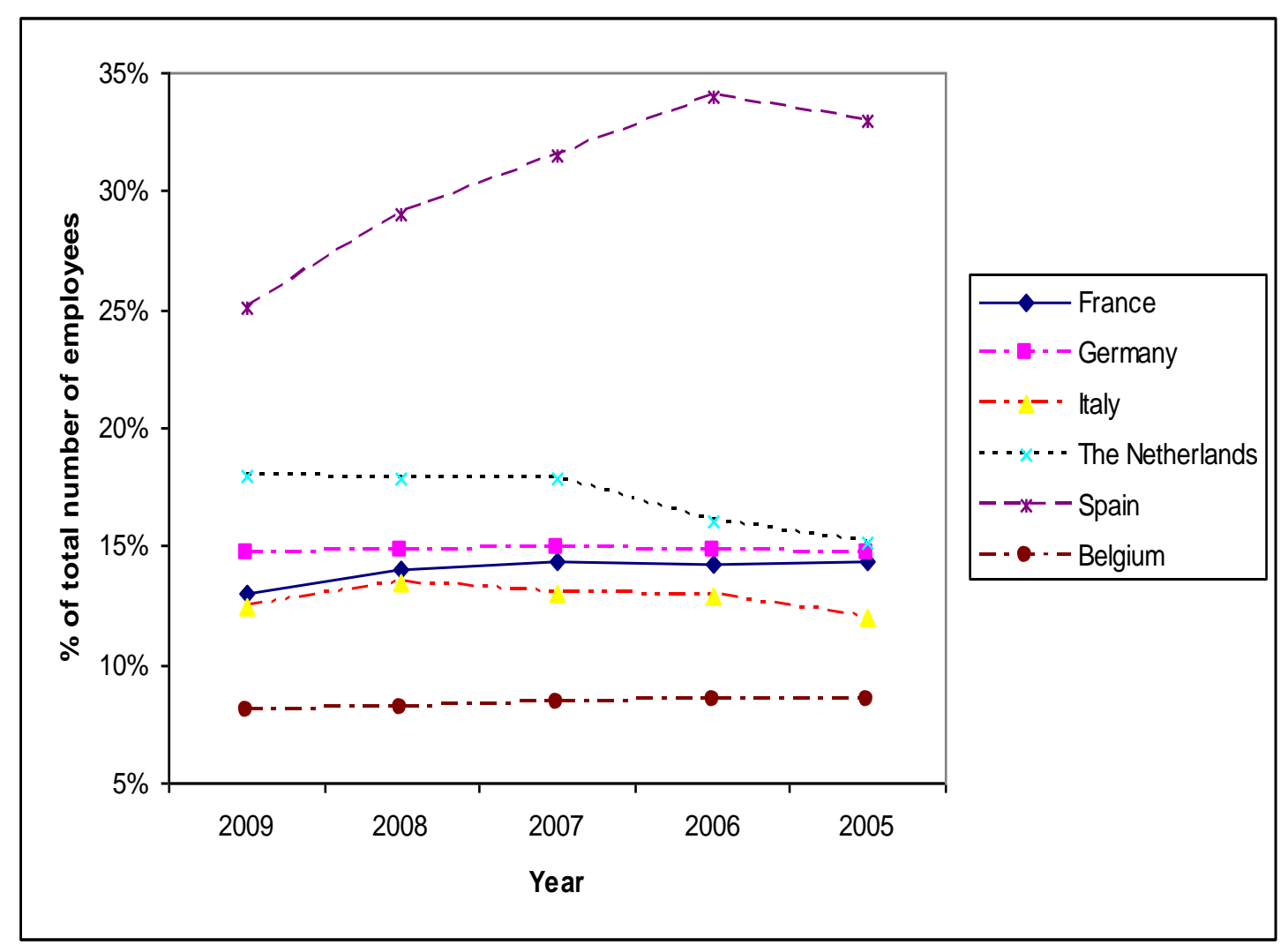

Source: Eurostat 
Figure 2. Effect of temporary hiring on labor productivity

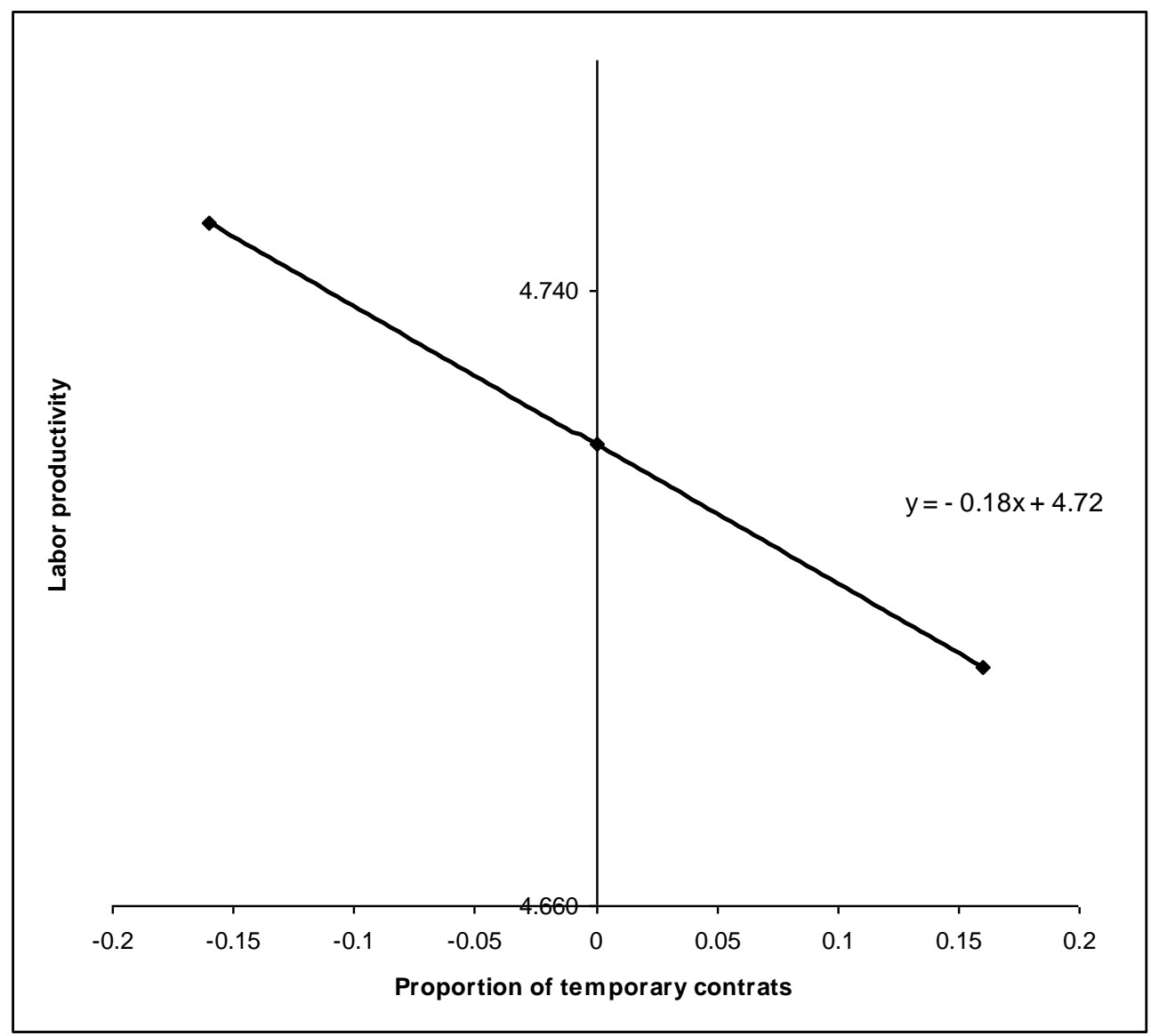


Figure 3. Effect of temporary hiring on gross operating margin
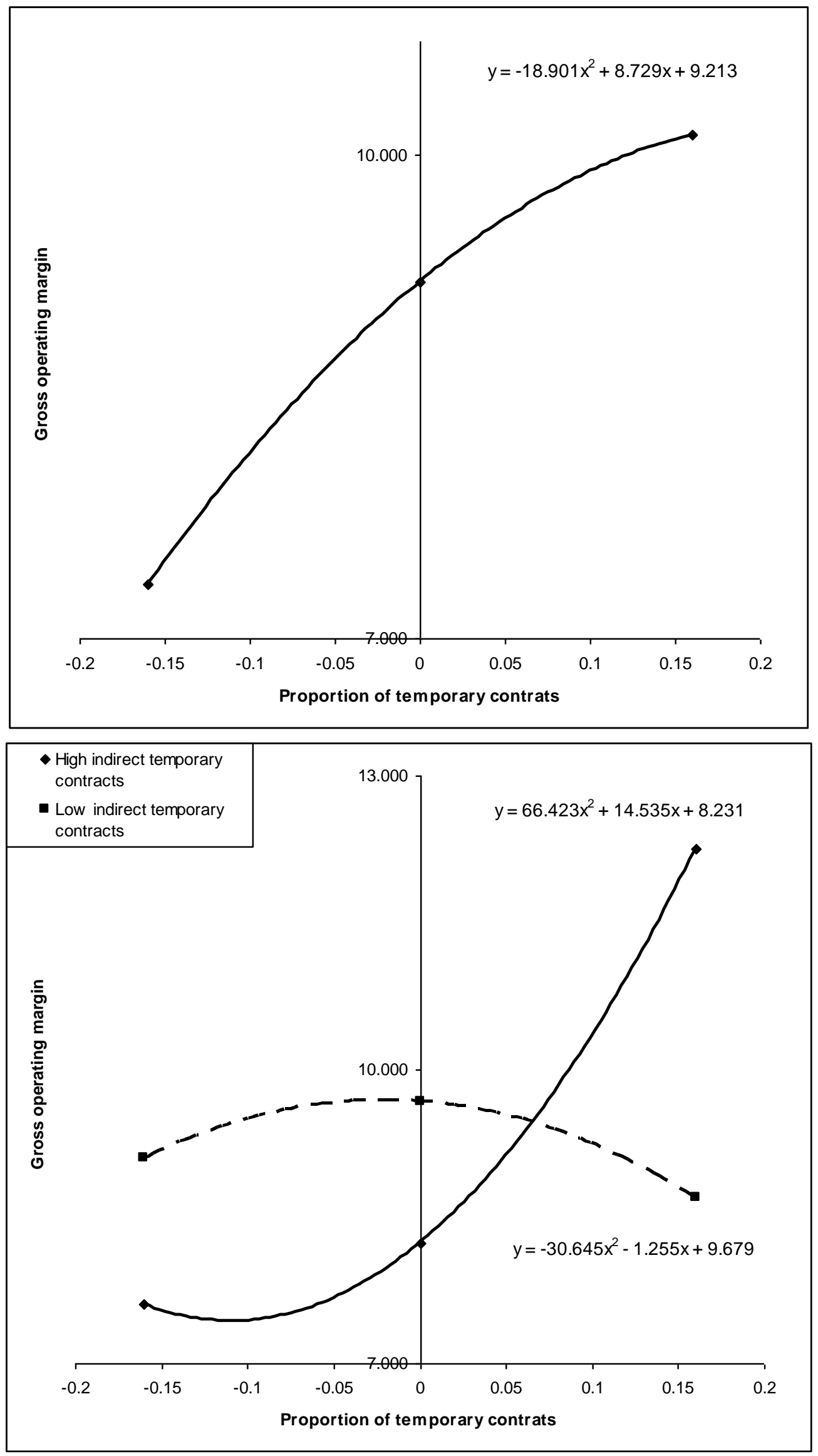